\title{
Arpada Farklı Gama Radyasyon Dozu Uygulamalarının M2 Generasyonunda Bazı Tarımsal Özellikler Üzerine Mutagenik Etkilerinin Belirlenmesi
}

\author{
Tuğçe Ayşe KARAKOCA ${ }^{1}$ (D) İlknur AKGÜN*2 (D) \\ 1,2Isparta Uygulamalı Bilimler Üniversitesi, Ziraat Fakültesi, Tarla Bitkileri Bölümü, 32000, Isparta, Türkiye
}

(Alınış / Received: 26.06.2019, Kabul / Accepted: 13.12.2019, Online Yayınlanma / Published Online: 20.04.2020)

\author{
Anahtar Kelimeler \\ Arpa, \\ Gama-ışını, \\ Bitki boyu, \\ Bașak özellikleri
}

\begin{abstract}
Özet: $\mathrm{Bu}$ çalışma, Tarm-92 iki sıralı arpa çeşidi tohumlarına uygulanan farklı dozlarda gama ıșınının $(200,300,400$ ve $500 \mathrm{~Gy}) \mathrm{M}_{2}$ bitkilerinde bazı tarımsal özellikler üzerine etkilerini belirlemek amacıyla yapılmıștır. Araştırma Isparta koşullarında 2016-2017 vejetasyon döneminde yürütülmüştür. Araştırmada kontrol (ışın uygulanmamıș), 200, 200 A, 300, 300 A, 400, 400 A, 400 A (Ç.B.) 500 ve 500 A gray dozları olmak üzere toplam 10 parsel yer almıştır. Parsellere dekara $10 \mathrm{~kg} /$ da azot ve $6 \mathrm{~kg} /$ da fosfor $\left(\mathrm{P}_{2} \mathrm{O}_{5}\right)$ hesabıyla gübre uygulanmıştır. Araştırmada gama ışınlarının bitki boyu, başak uzunluğu, başakta tane sayısı ve başakta tane ağırlı̆̆ı üzerine etkileri incelenmiştir. Araştırma sonucunda; ortalama bitki boyu kontrolde $72.10 \mathrm{~cm}, \mathrm{M}_{2}$ generasyonunda 55.19-70.22 cm; başak uzunluğu kontrolde $8.71 \mathrm{~cm}, \mathrm{M}_{2}$ generasyonunda 7.43-9.13 cm; bașakta tane sayısı kontrolde 23.49 adet, $\mathrm{M}_{2}$ generasyonunda 20.36-23.42 adet, başakta tane ağırlığı kontrolde $2.73 \mathrm{~g}$ iken $\mathrm{M}_{2}$ generasyonunda 1.25-2.46 g arasında değişim göstermiştir. İncelenen özelliklerden bitki boyu, başakta tane sayısı, başakta tane ağırlı̆̆ında kontrol grubuna göre gama radyasyon uygulaması ile genel olarak azalma, başak uzunluğunda artış gözlemlenmiştir. Araştırma sonucunda; 300 ve 400 Gy uygulamalarında incelenen özellikler yönünden daha fazla varyasyonun meydana geldiği belirlenmiştir.
\end{abstract}

\section{Determination of the Mutagenic Effect of Different Gamma Radiation Doses Applications on Some Agricultural Characteristics of Barley in $\mathbf{M}_{2}$ Generation}

Keywords

Barley,

Gamma-rays,

Plant length,

Spike characters

\begin{abstract}
This study was aimed to determine the effects of different doses of gamma radiation $\left(200,300,400\right.$ and $500 \mathrm{~Gy}$ ) on some agricultural properties of $\mathrm{M}_{2}$ generation of 'Tarm-92' barley variety. The research was conducted in 2016-2017 vegetation period under Isparta conditions. Total 10 plots were taken in the study as control (non-irradiated), 200, $200 \mathrm{~A}, 300,300 \mathrm{~A}, 400,400 \mathrm{~A}, 400 \mathrm{~A}$ (Ç.B.) 500 and 500 A gray doses. The plots were fertilized with $10 \mathrm{~kg} / \mathrm{da}$ nitrogen and 6 $\mathrm{kg} /$ da phosphorus $\left(\mathrm{P}_{2} \mathrm{O}_{5}\right)$. During the study the data on plant height, spike length, number of grain per spike and weight of grain per spike were collected. Results showed that average plant height was $72.10 \mathrm{~cm}$ in the control and ranged from 55.19 to $70.22 \mathrm{~cm}$ in $\mathrm{M}_{2}$ generation. Spike length ranged from 7.43 to $9.13 \mathrm{~cm}$ in $\mathrm{M}_{2}$ generation and was $8.71 \mathrm{~cm}$ in the control plants. The number of seed per spike was 23.49 in control, whereas it ranged from 20.36 to 23.42 in $\mathrm{M}_{2}$ generation. The seed weight per spike was $2.73 \mathrm{~g}$ in control and ranged from 1.25 to $2.46 \mathrm{~g}$ in $\mathrm{M}_{2}$ generation. While gamma radiation reduced plant height, number of seed per spike, weight of seed per spike it increased spike length compared to control plants in 'Tarm-92' barley variety. The results indicated that 300 and 400 Gy applications produced more variations in terms of examined agricultural characteristic.
\end{abstract}




\section{Giriş}

Hayvan beslenmesinde önemli yere sahip olan arpa tanesinin bünyesi, yaklaşık olarak \% 67 karbonhidrat, \% 10 protein, \% 2 yağ, \% 5 selüloz içermekte olup, kalsiyum, fosfor, potasyum gibi mineraller ile A, E ve B vitaminlerince de zengindir [1]. Ayrıca içerisindeki yüksek sindirilebilir lif oranı ve yüksek $\beta$-glukan oranından dolayı arpa, insan beslenmesinde önem kazanmaya başlamış ve bazı ülkelerde buğday ununa katkı maddesi olarak kullanıldığı bildirilmiștir [2]. Günümüzde dünyada üretimi yapılan arpanın kullanım alanları içerisinde, hayvan yemi (\% 68), sanayi amaçlı (\% 21) ve gıda endüstrisi ( $\% 5)$ sayılmaktadır. Türkiye'de ise hayvan yemi (\% 90) ve gıda endüstrisinde kullanılmaktadır [3].

Bitkisel üretimde istenilen miktarda üretim artışını sağlayabilmek amacıyla yapılacak çalışmaların başında, yüksek verim potansiyeli olan, yetiştirme şartlarına uyum gösteren, kalite özellikleri yönünden iyi, hastalık ve zararlılara karşı dayanıklı yeni çeşitlerin elde edilmesi, üretimdeki çeşitlerin geliştirilmesi ve yaygınlaştırılması gelmektedir [4]. Yeni çeşitlerin geliştirilmesinde kullanılacak yöntemlerden birisi de kolay ve kısa sürede sonuç veren mutasyon islahıdır. Mutasyon; kromozomlardaki sayı ve yapı değişiklikleri ile genlerdeki değişimler olarak ifade edilmektedir [5]. FAO/IAEA mutant çeşit listesine göre 2000 yılından önce 2252 adet çeşit, mutasyon yolu ile elde edilmiştir. Mutasyonla geliştirilen çeşit sayısı 1995 yılında 154 iken, 2000 yılında 175 olarak kaydedilmiştir. Geliştirilen çeşitlerin büyük bir çoğunluğu tahıllar (1072) grubundadır. Bu mutasyonların büyük bir çoğunluğu (\% 64) Gama ışınlaması sonucu elde edilmiştir [6].

$\mathrm{Bu}$ konuda yapılan bir çalışmada, tritikale (cv T77) ve arpa (cv C4) üzerine 5, 10, 20, 30 ve 40 krad (kR) gama ışınlarını uygulanmış ve $\mathrm{M}_{3}$ generasyonundaki bitki boyu, başak uzunluğu ve başakta tane sayısını incelenmiştir. Araştırma sonucunda, uygulanan gama dozlarıyla oluşturulan varyasyonun çeşide, radyasyon dozuna ve çeşitle doz arasındaki interaksiyona bağlı olduğu ve ayrıca, yüksek radyasyon dozlarının çok daha zararlı etki yaptığı bildirilmiştir [7]. Diğer bir çalışmada, buğday genotiplerine farklı gama dozlarının $(0,15,25,35$ ve $45 \mathrm{kR}$ ) $\mathrm{M}_{1}$ bitkilerindeki etkilerini araştırmışlar ve çalışma sonucunda 25 kR'tan yüksek dozlarda başaklanmanın geciktiği ve 15 kR'lık dozda en hızlı başaklanmanın olduğu belirlenmiştir [8].

Arpada mutasyon çalışmalarında farklı fiziksel ve kimyasal mutagen kaynakları kullanılmaktadır. Gamma ışını olarak en fazla kullanılan doz 150-400 Gray arasındadır. FAO/ IAEA listelerinde resmi olarak kayıtlı 269 mutant arpa çeşidi yer almaktadır. Bunlardan 53 tanesi doğrudan çeşit olarak kullanıldığı, 216 tanesinin ise melezlemelerde ebeveyn olarak yer aldığı tespit edilmiştir. Özellikle yarı bodurluk sağlayan genler birçok çeşide aktarılmıştır. Yine sağlam saplı, yüksek verimli, malt kalitesi geliştirilmiş Golden Promise çeşidi Avrupa'da yaygın olarak yetiştirilmekte olduğu bildirilmiştir [9]. Bu veriler günümüz uygulamalarında mutasyonun, bitki ıslahında kullanıldığını göstermektedir.

Ülkemizde arpa üzerinde çeşit geliştirme ve yetiştirme tekniği çalışmalarına Cumhuriyetin ilk yıllarında Eskişehir, Ankara ve Yeșilköy Araștırma İstasyonları ve 1933'de Yüksek Ziraat Enstitüsünün kurulmasıyla başlanılmış ve giderek hız kazanmıştır [10]. Bu çalışmada arpada mutasyon ıslahı ile kalite ve veriminin artırılması hedeflenmiștir. Çalışmada amaç, iki sıralı arpa çeşidi 'Tarım-92' üzerinde farklı gama dozu ıșınlarının $\mathrm{M}_{2}$ generasyonundaki bazı tarımsal özellikler üzerine etkileri incelenmiştir.

\section{Materyal ve Metot}

$\mathrm{Bu}$ çalışmada Tarm-92 arpa çeşidi tohumlarına 2016 yılında Türkiye Atom Enerjisi Kurumu'nda mutagen olarak 0.6 megarad/saat gücündeki kobalt-60 kaynağından elde edilen gama ışınları kullanılmıştır. Araştırmada tohumlara 200, 300, 400,500 ve 600 Gray doz gama radyasyonu uygulanmış ve her uygulamada 2500 tohum radyasyona tabi tutulmuş ve o yıl sera şartlarında ekimi yapılmıştır. Hasat sonucu elde edilen tohumlarl, her dozdan başak ve bitki görünümüne göre normal görünümlü ve anormal görünümlü olarak gruplandırılıp (Örneğin 200 Gy kontrol grubunun başak yapısına, 200 (A) Gy anormal bașak yapısı küçük, tohum tutmamış ya da büyük) farklı parsellere bir sonraki generasyonu oluşturmak üzere ekilmiştir. 2016 yılı vejetasyon döneminde 600 Gy dozunda çıkış olmadığından, bu doz denemeye alınmamıştır. Ayrıca 400 Gy dozu uygulamasında çift başak oluşumu ve başakta dallanma eğilimi gösteren bitkilere (ÇB) rastlanmış, 400 (A) Gy anormal grubuna dahil edilmemiş, ayrı bir sıra olarak ekilmiştir.

Araştırmada kontrol (ışın uygulanmamış), 200, 200 A, 300, 300 A, 400, 400 A, 400 A (ÇB) 500 ve 500 A gray dozları olmak üzere toplam 10 parsel yer almıştır. Denemede her gruptan elde edilen tohum miktarına bağlı olarak parsellerde sıra sayısı değişmiştir. Kontrol 5 sıra, 200 Gy 5 sıra, 200A Gy 8 sira, 300 Gy 7 sira, 300A Gy 4 sira, 400 Gy 4 sira, 400A Gy 5 sira, 400A (Ç.B.) Gy 1 sira, 500 Gy 6 sira, 500A Gy 1 sıra olacak şekilde ekim yapılmıştır. Araştırmada parseller sıra uzunluğu $4 \mathrm{~m}$, sıra arası mesafe $30 \mathrm{~cm}$ olacak şekilde düzenlenmiştir. Parseller arasında ilave bir mesafe bırakılmamıștır. 
Çalışmada tüm parsellere $10 \mathrm{~kg} / \mathrm{da}$ azot ve $6 \mathrm{~kg} / \mathrm{da}$ fosfor $\left(\mathrm{P}_{2} \mathrm{O}_{5}\right)$ hesabıyla gübreleme yapılmıştır. Azotlu gübrenin yarısı ekimle birlikte amonyum sülfat formunda, diğer yarısı ise sapa kalkma devresinde amonyum nitrat formunda, fosforlu gübrenin tamamı ise ekimle birlikte triple süper fosfat gübresi kullanılarak verilmiştir. Olgunlaşma tamamlandıktan (tam olum döneminde) sonra kontrol bitkilerde başlangıç sırası kenar tesiri olarak atıldıktan sonra kalan (4 sira) sira ve radyasyon uygulamasına tabi tutulan tüm bitkileri toprak yüzeyinden el ile hasat edilmiştir. Her bitki ayrı ayrı ölçümler yapılarak harmanı yapılmıştır. Ayrıca, 500 A Gy grubunda çıkış olmadığından bu uygulama deneme dıșı bırakılmıştır.

Denemenin yürütüldüğü dönemde ortalama sıcaklık $\left(9.8^{\circ} \mathrm{C}\right)$ ve toplam yıllık yağış miktarının (467.2 mm) aynı döneme ait uzun yıllar ortalamasından (ortalama sıcaklık $10.1{ }^{\circ} \mathrm{C}$; toplam yağış $500.5 \mathrm{~mm}$ ) daha düşük olduğu belirlenmiștir (Tablo 1).

Deneme alanından 0-30 cm derinliğinde alınan toprak örneklerinin analiz sonuçlarına göre; toprağın strüktürü killi-tınlı bir yapıya sahip olup, hafif alkali (pH 7.9), organik madde (0.85), kireç oranı \% 29.48 ve fosfor içeriği yetersiz $(7.20 \mathrm{~kg} / \mathrm{da})$, potasyum $(176.24 \mathrm{~kg} / \mathrm{da})$ bakımından ise yeterli seviyeye sahiptir.

Çalışmada hasat edilen tüm bitkilerde (ana sap ve kardeşler) bitki boyu (cm), başak boyu (cm), başakta tane sayısı (adet) ve başakta tane ağırlığı (g) özelliklerine ait veriler tek bitki üzerinden elde edilmiştir. Kontrol grubunda 100 bitki üzerinden değerlendirmeler yapılmış, diğer uygulama gruplarında ise başak oluşturan tüm bitkiler değerlendirmeye alınmıştır. Araştırmada tüm uygulamalarda kardeşler tam olarak ayrılamadığı için ana sapın yanında kardeşlerin başaklarında da ölçüm yapılmıștır. Elde edilen bu verilerde MINITAB istatistik paket programında önce ortalama, minimum, maksimum ve standart sapma değerleri belirlenmiş daha sonra discriminant (ayırma) analizi yapılmıştır.

\section{Bulgular ve Tartışma}

\subsection{Bitki boyu}

Kobalt $60\left({ }^{60} \mathrm{Co}\right)$ gama dozu uygulanan iki sıralı Tarm-92 arpa çeşidinin $\mathrm{M}_{2}$ generasyonunda bitki boyu ortalamasına ait değerler Tablo 2'de verilmiştir. Araştırmada sıralardaki tüm hasat edilen bitkilerin boyları ölçülerek bitki boyu değerleri elde edilmiştir. $\mathrm{Bu}$ nedenle kontrol grubu bitki boyunda $(55-86 \mathrm{~cm})$ geniş varyasyon meydana gelmiştir.

Araştırmada $\mathrm{M}_{1}$ generasyonunda oluşturulan farklı dozlardaki gama gruplarının döllerinde $\left(\mathrm{M}_{2}\right.$ generasyonu) en yüksek ortalama bitki boyu 72.10 $\mathrm{cm}$ ile kontrol grubunda belirlenmiștir. Gama uygulaması bitki boyunda azalmaya neden olmuş ve en düşük ortalama bitki boyu $55.19 \mathrm{~cm}$ ile $\mathrm{M}_{1}$ generasyonunda 300 anormal (A) grup olarak ayrilan örneklerden elde edilmiştir. Yine 200 anormal grupta ortalama bitki boyu $58.35 \mathrm{~cm}$ ile bazı gruplardan daha düşük bulunmuștur. Gama uygulamasından sonra $\mathrm{M}_{1}$ generasyonunda, kontrole benzeyen başaklarda herhangi bir anormallik bulunmayan örnek gruplarında (200 Gy, 300 Gy, 400 Gy, 500 Gy) ortalama bitki boyu kontrol grubundan daha düşük bulunmuş ve sırasıyla $61.21 \mathrm{~cm}, 60.99 \mathrm{~cm}, 59.31 \mathrm{~cm}$ ve $65.48 \mathrm{~cm}$ olmuştur. Çift başaklı olarak ayrı sıraya ekilmiș örnek grubunda ise ortalama bitki boyu 70.22 $\mathrm{cm}$ ile kontrole en yakın grubu olușturmuștur. Ancak diğer gama dozu gruplarında olduğu gibi, bu grup içerisinde de kontrole göre daha kısa $(33.00 \mathrm{~cm})$ ve daha uzun bitkiler $(92.00 \mathrm{~cm})$ belirlenmiştir. Araştırmada her uygulamadaki maksimum ve minimum değerler incelendiğinde $400 \mathrm{~A}$ ve 500 gray doz uygulamalarında en uzun $(96.00 \mathrm{~cm})$ ve $300 \mathrm{~A}$ gray doz uygulamasında ise en kisa $(21.00 \mathrm{~cm})$ bitkiler elde edilmiştir (Tablo 2).

Tablo 1. Isparta ili denemenin yürütüldüğü yıl ve uzun ylllara ait iklim verileri*

\begin{tabular}{lcccccc}
\hline \multirow{2}{*}{ Aylar } & \multicolumn{2}{c}{ Ortalama Sicaklık $\left({ }^{\circ} \mathrm{C}\right)$} & \multicolumn{2}{c}{ Toplam Yağış (mm) } & \multicolumn{2}{c}{ Ortalama Nispi Nem (\%) } \\
\cline { 2 - 6 } & $2016-2017$ & $\begin{array}{c}\text { Uzun Yllar } \\
\text { Ortalaması** }\end{array}$ & $2016-2017$ & $\begin{array}{c}\text { Uzun Ylllar } \\
\text { Ortalaması }\end{array}$ & 2016-2017 & $\begin{array}{c}\text { Uzun Yıllar } \\
\text { Ortalaması }\end{array}$ \\
\hline Kasım & 7.2 & 7.8 & 48.8 & 45.2 & 64.7 & 70.0 \\
Aralık & 0.3 & 3.5 & 33.5 & 87.5 & 69.5 & 75.8 \\
Ocak & 0.8 & 1.8 & 87.8 & 80.8 & 77.9 & 75.2 \\
Şubat & 3.0 & 2.9 & 3.6 & 68.1 & 68.5 & 71.6 \\
Mart & 7.3 & 5.9 & 74.4 & 59.1 & 64.1 & 66.0 \\
Nisan & 10.6 & 10.7 & 25.6 & 52.9 & 59.6 & 61.5 \\
Mayıs & 14.9 & 15.4 & 149.5 & 56.7 & 63.7 & 59.2 \\
Haziran & 20.1 & 19.8 & 30.9 & 33.6 & 58.9 & 52.5 \\
Temmuz & 25.2 & 23.4 & 13.1 & 16.3 & 41.9 & 45.7 \\
\hline Ort./Top. & 9.8 & 10.1 & 467.2 & 500.5 & 63.20 & 64.17 \\
\hline
\end{tabular}

*:Kaynak: Meteoroloji Genel Müdürlüğü

**: Uzun yıllar 1929 ile 2018 yılları arasındaki iklim verileridir 
Tablo 2. Farklı gama dozu uygulanan Tarm-92 arpa çeşidinin $\mathrm{M}_{2}$ generasyonuna ait bitki boyu (cm)

\begin{tabular}{lcccc}
\hline Uygulama Dozu (Gy) & $\mathrm{N}$ & Ortalama std & $\begin{array}{c}\text { Minimum } \\
\text { Değer }\end{array}$ & $\begin{array}{c}\text { Maksimum } \\
\text { Değer }\end{array}$ \\
\hline Kontrol & 100 & $72.10 \pm 6.87$ & 55.00 & 86.00 \\
200 & 140 & $61.21 \pm 17.74$ & 23.00 & 91.20 \\
$200 \mathrm{~A}$ & 175 & $58.35 \pm 13.93$ & 30.00 & 88.00 \\
300 & 193 & $60.99 \pm 15.75$ & 29.00 & 91.50 \\
$300 \mathrm{~A}$ & 256 & $55.19 \pm 18.19$ & 21.00 & 92.00 \\
400 & 149 & $59.31 \pm 15.32$ & 23.00 & 86.30 \\
$400 \mathrm{~A}$ & 170 & $64.19 \pm 17.61$ & 24.50 & 96.00 \\
$400 \mathrm{~A}$ (C..B.) & 77 & $70.22 \pm 13.36$ & 33.00 & 92.00 \\
500 & 180 & $65.48 \pm 14.99$ & 29.00 & 96.00 \\
\hline
\end{tabular}

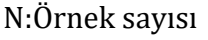

Çalışmada ortalama bitki boyu değerleri incelendiğinde, gama ışını uygulaması kontrole göre bitki boyunu azaltmıştır. Ancak kontrole göre farklı gama dozlarında daha uzun bitkiler de belirlenmiştir. Arpa için önemli kayıplara neden olan problemlerin bașında yatma sorunu gelmektedir. Yatma, hem başak kırılmasına hem de makinalı hasadın yapılmasını engelleyen ve verim kayıplarına yol açan önemli bir problemdir. $\mathrm{Bu}$ durumu ortadan kaldırmak amacıyla bitki boyunun kısaltılması ve sap sağlamlığının arttırılması gerekmektedir [11].

Arpada başakların tane dolum dönemine girdiğinde bitkinin yatmasındaki ana etmenin uzun boyluluk olduğu ve bitki boyunun eklemeli gen ile yönetildiği bildirilmiştir. Yine uzun boylu bitkilerin, fotosentez ürünü olan asimilatları bitki boyu uzaması için kullandığı, kısa boylu bitkilerin ise, bu ürünleri fertil kardeş oluşturmada kullanmakta ve bu durumunda dolaylı olarak tane verimine etki etmektedir $[12,13]$.

Bilge ve Ersoy [14], arpada 20 Gy gibi düşük dozun bitki boyunda artışa sebep olduğunu ve artan dozlarla birlikte $(40,80$ ve 120 Gy) bitki boyunda azalmaların meydana geldiğini gözlemlemişlerdir. Başer vd. [15], makarnalık buğdayda; Katipoğlu [16], Kaya adlı iki sıralı ve Gem adlı altı sıralı arpa çeşitlerinde farklı gama dozları $(0,10,20$ ve $30 \mathrm{kR})$ uygulamışlar ve sonuç olarak, kontrole göre bitki boyunda önemli azalmalar meydana geldiğini bildirmişlerdir. Bouma ve Ohnoutka [17] ise, Valticky arpa çeşidinde gama ışıması uyguladıklarında kontrole göre $15 \mathrm{~cm}$ daha kısa bitkiler elde etmişlerdir. Yapılan pek çok çalışmada mutagen uygulamalarının bitki boyunda önemli kisalmaya neden olduğunu bildirmektedir [18,19]. Farklı araştırma sonuçları, elde ettiğimiz sonuçlar ile benzerlik göstermektedir.

\subsection{Başak uzunluğu}

Kobalt $60\left({ }^{60} \mathrm{Co}\right)$ gama dozu uygulanan iki sıralı Tarm-92 arpa çeşidinin $\mathrm{M}_{2}$ generasyonunda başak uzunluğu ortalamasına ait değerler Tablo 3'te verilmiştir. $\mathrm{M}_{2}$ generasyonunda, araştırmanın $\mathrm{M}_{1}$ generasyonundan elde edilen çift başak veya başakta dallanma gibi anormallik gösteren başakların döllerinde bu anormalliklere rastlanmamıștır. $\mathrm{Bu}$ oluşumun kalıtsal olmadığı başlangıç generasyonunda mitoz bölünme anormalliğinden kaynaklandığı tespit edilmiştir. Çalışmada $\mathrm{M}_{2}$ generasyonuna ait en yüksek ortalama başak uzunluğu $9.13 \mathrm{~cm}$ ile 400 A (Ç.B.) gurubunda belirlenmiştir. Kontrol grubu $8.71 \mathrm{~cm}$ ortalama başak uzunluğu ile 400 A (Ç.B.) grubu bitkilerine en yakın grubu oluşturmuştur. Diğer doz uygulamaları bu iki grubun ortalamasından daha düşük çıkmakla beraber, en düşük ortalamaya ve anormal başak yapısı görünümüne sahip grup $7.43 \mathrm{~cm}$ ile $300 \mathrm{~A}$ grubudur. Bu uygulamaları sirasiyla 400 A Gy (8.42 $\mathrm{cm}), 200$ ve $500 \mathrm{~Gy}(8.35 \mathrm{~cm})$ dozları takip etmiştir. Uygulamada kontrole göre daha kısa (300 A Gy dozu $3.50 \mathrm{~cm}$ ) ve daha uzun (200 A Gy dozu $13.00 \mathrm{~cm}$ ) başak yapısına sahip bitkiler belirlenmiştir (Tablo 3).

Başak uzunluğunun artması, başaktaki fotosentetik kapasitenin yükseltilmesi bitki ıslahçıları tarafından istenen bir özelliktir. Uzun başak yapısına sahip arpalarda tane miktarı fazla olacağından, tane verimi de artacaktır. Başak uzunluğu kalıtım derecesinin yüksek olması nedeniyle, tane verimi için seleksiyonda önemli bir kriterdir [20]. Yine tane verimi ve başak uzunluğu arasında olumlu ve önemli $\left(0.656^{* *}\right)$ bir ilişki tespit edilmiştir [21]. Yıldırım ve Budak [22], 'Kaya' arpa mutant hatları ve kontrol grup arasında bașak uzunluğu ve bitki boyu yönünden önemli bir farklılığın bulunmadığını bildirmişlerdir. Çalışmadan elde edilen veriler sonucunda başak uzunluğu 400 A (Ç.B.) Gy dozunda kontrol grubundan $(8.71 \mathrm{~cm})$ daha yüksek olarak belirlenmiş olup, uygulamalara göre başak uzunluğu ise 7.43-9.13 $\mathrm{cm}$ arasında değişmiştir (Tablo 3).

Güllap [18], yazlık arpada gama uygulaması sonucunda, kontrol grubunda başak uzunluğunun 8.6 $\mathrm{cm}$, mutant arpaların ise 7.9-11.8 cm arasında değişim gösterdiğini bildirmiştir. Benzer şekilde yapılan bazı çalıșmalarda, uygulanan mutagen cinsine ve dozlarına bağlı olarak başak uzunluğunda artma $[19,23]$ ve azalmalar gözlemlenmiştir [24]. 
Tablo 3. Farklı gama dozu uygulanan Tarm-92 arpa çeșidinin $\mathrm{M}_{2}$ generasyonuna ait bașak uzunluğu (cm)

\begin{tabular}{lcccc}
\hline Uygulama Dozu (Gy) & $\mathrm{N}$ & Ortalama \pm std & $\begin{array}{c}\text { Minimum } \\
\text { Değer }\end{array}$ & Maximum Değer \\
\hline Kontrol & 100 & $8.71 \pm 1.00$ & 6.50 & 11.50 \\
200 & 140 & $8.35 \pm 1.36$ & 4.00 & 10.90 \\
$200 \mathrm{~A}$ & 175 & $8.25 \pm 1.64$ & 4.00 & 13.00 \\
300 & 193 & $7.88 \pm 1.53$ & 4.50 & 11.50 \\
$300 \mathrm{~A}$ & 256 & $7.43 \pm 1.50$ & 3.50 & 11.00 \\
400 & 149 & $8.20 \pm 1.44$ & 4.30 & 11.00 \\
$400 \mathrm{~A}$ & 170 & $8.42 \pm 1.68$ & 4.50 & 12.00 \\
$400 \mathrm{~A}$ (Ç.B.) & 77 & $9.13 \pm 1.03$ & 7.00 & 12.00 \\
$500 \quad$ N:Örnek sayısı & 180 & $8.35 \pm 1.47$ & 4.50 & 12.50 \\
\hline \multicolumn{2}{c}{} \\
\multicolumn{2}{c}{}
\end{tabular}

\subsection{Başakta tane sayısı}

Gama uygulaması başakta tane sayısında genel olarak azalmaya neden olmuştur. $\mathrm{M}_{2}$ generasyonunda incelenen bitkilerin ortalama başakta tane sayısı kontrol grubu dıșında 20.36-23.42 adet arasında değişmiştir. En yüksek ortalama başakta tane sayısı 23.49 adet ile kontrol grubundan elde edilmiştir. Yine 400 Gy ve 400 A Gy gruplarında ortalama başakta tane sayısını sirasıyla 23.42 ve 23.24 adet ile kontrol grubuna en yakın değerler elde edilmiştir (Tablo 4). $\mathrm{M}_{2}$ generasyonunda $300 \mathrm{~A}$ Gy grubu 20.36 adet ile en düşük tane sayısı ortalamasına sahip olmuştur.

$\mathrm{M}_{2}$ generasyonunu olușturan farklı grupların maksimum ve minimum değerleri incelendiğinde, 200 A grubunda en yüksek (44 adet), 400 A (Ç.B.) olarak tanımladığımız grup içerisinde ise en düşük (15 adet) başakta tane sayısı olan bitkiler belirlenmiştir. 400 A (Ç.B.) grubunda başak uzunluğu diğer gruplardan fazla olmasına rağmen başakta tane sayısında artış meydana gelmemiştir. Bu durum başağın seyrek yapılı ya da başakçıklardaki çiçeklerin kısır olduğunu göstermektedir. 400 ve $400 \mathrm{~A}$ gruplarında ortalama başak uzunluğu başakta tane sayısı birbirine yakın bulunmuştur. Yine radyasyona maruz bırakılan her grup kendi içerisinde değerlendirildiğinde (Örneğin 200 ve 200 A gibi) anormal başak yapısına sahip bitkilerde ortalama tohum tutma azalmıștır (Tablo 4).

Mutagen dozlarına bağlı olarak kısırlığın arttığı ve başakta tane sayısının azaldığı farklı araştırmalarda belirlenmiştir. Özellikle gama radyasyonu ile metafaz I'de univalent frekansında ve anafaz I'de görülen kromozom anormalliklerinde artış meydana gelmektedir [25, 26]. Mayoz bölünme anormallikleri tohum tutmayı önemli seviyede azaltmaktadır. Çok yıllık çavdara farklı radyasyon dozlarının uygulandığı çalışmada, $25 \mathrm{kR}$ gama radyasyonunda tohum tutma oranı (\%9.39) kontrole göre önemli seviyede $(\%$ 82.28) azalmıştır. Buna ilaveten, başaktaki tohum sayısının da radyasyon dozundaki artışa bağlı olarak azaldığını ve en düşük başakta tohum sayısı $25 \mathrm{kR}$ gama ıșınından elde edildiğini bildirmișlerdir. Ayrıca başakların büyük çoğunluğunun kısır olduğunu tespit etmişlerdir [26]. Yine mutagen uygulamaları anormal başak yapısı, generatif gelişmenin engellenmesi, çiçekteki dişi ve erkek organlarda bozulmalar ve anormal tohum gelişimine bağlı olarak embriyonun gelişmemesi gibi anormalliklerin ilk generasyonlarda daha sık rastlandığı farklı araștırmacılar tarafından bildirilmiştir $[26,27,28]$.

Tahıllarda verimi doğrudan etkileyen özelliklerden birisi de başaktaki tane sayısıdır. Bu nedenle verimi artırma amaçlı yapılan ıslah çalışmalarında özellikle başaktaki tane sayısı büyük önem taşımaktadır. Ayrıca Rachovska ve Dimova [29], başakta tane sayısının, gama ışını uygulanan tohumlarda en hassas özellik olduğunu bildirmiştir.

Yıldırım ve ark. [30], tarafından yapılan çalışmada iki farklı arpa çeşidine 15 ve $30 \mathrm{kR}$ gama radyasyon dozu uygulamışlardır. Araştırma sonucunda başak uzunluğu, başakçık sayısı ve başakta tane sayısının kontrole göre daha fazla olduğunu bildirmişlerdir. Yapılan diğer araștırmalarda da mutagen uygulamalarına bağlı olarak bazılarında tane sayısının arttığı [19], bazılarında ise azaldığı [31] ortaya konulmuştur. Peşkircioğlu ve ark. [32], arpada farklı dozlarda $(100,150,200,250$ Gy) gama uygulaması çalışmasında başakta tane sayısının 23.927.4 adet arasında değiștiğini saptamıșlardır. Arpa üzerinde yapılan çalışmalarda başakta tane sayısının, Sirat ve Sezer [33], 21.0-22.6 adet; İmamoğlu ve Yılmaz [34], 20.00-28.9 adet arasında değiștiğini bildirmişledir.

\subsection{Başakta tane ağırlığı}

Araştırmada gama ışını uygulanan $\mathrm{M}_{2}$ bitkilerinin ortalama bașakta tane ağırlığı 1.25-2.46 g arasında değișmiştir. Radyasyon uygulanan tüm dozlarda başakta tane ağırlığı kontrol grubu ortalamasından (2.73 g) daha düşük bulunmuştur. En düşük başakta tane ağırlığı 400 grubunda tespit edilmiştir (Tablo 5). 
Tablo 4. Farklı gama dozu uygulanan Tarm-92 arpa çeșidinin $\mathrm{M}_{2}$ generasyonuna ait bașakta tane sayısı (adet)

\begin{tabular}{lcccc}
\hline Uygulama Dozu (Gy) & $\mathrm{N}$ & Ortalama \pm std & Minimum Değer & $\begin{array}{c}\text { Maximum } \\
\text { Değer }\end{array}$ \\
\hline Kontrol & 100 & $23.49 \pm 5.26$ & 14.00 & 37.00 \\
200 & 140 & $22.84 \pm 4.90$ & 9.00 & 34.00 \\
$200 \mathrm{~A}$ & 175 & $22.04 \pm 6.46$ & 9.00 & 44.00 \\
300 & 193 & $21.21 \pm 4.98$ & 2.00 & 33.00 \\
$300 \mathrm{~A}$ & 256 & $20.36 \pm 4.01$ & 6.00 & 32.00 \\
400 & 149 & $23.42 \pm 4.09$ & 8.00 & 32.00 \\
$400 \mathrm{~A}$ & 170 & $23.24 \pm 5.09$ & 9.00 & 33.00 \\
$400 \mathrm{~A}$ (Ç.B.) & 77 & $21.06 \pm 4.01$ & 15.00 & 30.00 \\
500 & 180 & $20.69 \pm 4.23$ & 10.00 & 31.00 \\
\hline \multicolumn{2}{c}{ N:Örnek sayısl } & & &
\end{tabular}

Tablo 5. Farklı gama dozu uygulanan Tarm- 92 arpa çeşidinin $\mathrm{M}_{2}$ generasyonuna ait başakta tane ağırlığı (g)

\begin{tabular}{lcccc}
\hline Uygulama Dozu (Gy) & $\mathrm{N}$ & Ortalama \pm std & $\begin{array}{c}\text { Minimum } \\
\text { Değer }\end{array}$ & $\begin{array}{c}\text { Maximum } \\
\text { Değer }\end{array}$ \\
\hline Kontrol & 100 & $2.73 \pm 0.37$ & 1.95 & 4.09 \\
200 & 140 & $2.09 \pm 0.44$ & 0.90 & 3.05 \\
$200 \mathrm{~A}$ & 175 & $2.46 \pm 0.50$ & 1.26 & 3.35 \\
300 & 193 & $1.97 \pm 0.81$ & 0.06 & 3.26 \\
$300 \mathrm{~A}$ & 256 & $1.80 \pm 0.96$ & 0.05 & 3.57 \\
400 & 149 & $1.25 \pm 0.41$ & 0.07 & 1.94 \\
$400 \mathrm{~A}$ & 170 & $1.90 \pm 0.71$ & 0.66 & 3.34 \\
$400 \mathrm{~A}$ (Ç.B.) & 77 & $2.40 \pm 0.26$ & 1.89 & 3.12 \\
500 & 180 & $2.39 \pm 0.33$ & 1.43 & 3.64 \\
\hline
\end{tabular}

N: Örnek Sayısı

Araştırmada incelenen gruplara ait bitkilerin ortalama başakta tane sayllarl, kontrol (23.49 adet), 400 (23.42 adet) ve $400 \mathrm{~A}$ (23.24 adet) gruplarında daha fazla bulunmuştur. Ortalama başakta tane sayıları kontrol grubuna benzerlik göstermiș olmasına rağmen, 400 ve 400 A grubuna ait bitkilerin başakta tane ağırlığı düşük bulunmuştur (Tablo 5). Bu durum gama radyasyon uygulamasına bağlı olarak anormal tohum gelişimine açıklanabilir. Tohum tutmayı azaltan mayoz bölünmedeki anormallikler gibi, döllenmeden sonra embriyo ve endosperm gelişimi sağlayan mitoz bölünmede de anormalliklerin meydana geldiğini göstermektedir.

Başakta tane ağırlığı, tane verimini oluşturan kantitatif bir özelliktir. Çeşit geliştirmeye dayalı ıslah çalışmalarında, başakta tane sayısı ile tane ağırlı̆̆ı birlikte değerlendirilmektedir. Nitekim, farklı ekmeklik buğday çeşitlerinin kullanıldı̆̆ çalıșmada $100,200,300,400$ ve 500 Gy gama ıșını uygulanmıştır. $\mathrm{M}_{2}$ generasyonuna ait bitkilerin ortalama başakta tane ağırlığı 1.2-1.65 g arasında değişmiş ve kontrol grubundan daha düşük tane ağırlığı bulunmuştur. $\mathrm{Bu}$ çalışmada Bezostaja çeşidinde yüksek (500 Gy) ve düşük (100 ve $200 \mathrm{~Gy}$ ) radyasyon dozlarında kontrolden daha yüksek tane ağırlığı tespit edilmiştir. Genel olarak başakta tane sayısı fazla olan dozlarda, tane ağırlığı da fazla bulunmuştur. Ancak Kate A-1 çeşidinin radyasyon dozlarına tepkisi farklı olmuş, 100 Gy dozu haricinde tüm uygulamalarda başakta tane ağırlı̆̆ı azalmıştır. Araştırma sonucunda bitki boyu ve başakta tane sayısının gama radyasyonuna en hassas özellik olduğunu bildirmişlerdir. 200 ile 300 Gy radyasyonunun verim ve verim öğelerini arttırmada faydalı doz olduğunu ileri sürmüşlerdir [35].
Bu konuda yapılan başka bir çalışmada makarnalık buğdaya farklı dozlarda (100. 200. 300. 400 ve 500 Gy) gama ışını uygulanmıștır. Araștırma sonucuna göre ana saptaki başakta tane ağırlığı 100 ve 300 Gy dozlarında kontrole göre daha fazla olmuş ve $300 \mathrm{~Gy}$ dozunda istenilen özellikler yönünden varyasyon bulunduğu ileri sürülmüştür [19]. Peşkircioğlu ve ark. [32], tarafından yapılan bir çalıșmada arpaya farklı gama dozları uygulanmıştır. Araştırmada tek bitki verimi 8.1-9.5 g arasında değişmiş ve artan gama radyasyon dozu tek bitki verimini arttırmıştır. Ancak en yüksek dozda (250 Gy) tek bitki verimi kontrol ile benzer bulunmuștur (9.5 g). Diğer taraftan Khan vd. [36], arpada 10.20 ve $30 \mathrm{kR}$ gama dozlarının başakta tane sayısını çok az etkilediği veya hiç etkilemediğini, $40 \mathrm{kR}$ ve üstü dozların ise arpada bazı verim öğelerine olumsuz etki yaptığını bildirmişlerdir. Farklı arpa genotiplerinin kullanıldığı çalışmalarda başakta tane ağırlığını Sirat ve Sezer [33] 1.2-2.5 g olarak bulurken, İmamoğlu ve Yılmaz [34], bu değerin 1.0-2.3 g arasında değiștiğini bildirmişlerdir.

\subsection{Diskriminant (Ayırma) analiz sonuçları}

Gama ıșını uygulaması sonucunda incelenen özellikler yönünden ayırmadaki toplam başarı oranı \%29 olarak bulunmuştur (Tablo 6). Başarı oranının düşük olmasının $\mathrm{M}_{1}$ generasyonunda herhangi bir seleksiyon yapılmadan tüm bitkilerin $\mathrm{M}_{2}$ generasyonunda değerlendirmeye alınmasından kaynaklandığı düşünülmektedir. Mutagen grupları ayrı ayrı değerlendirildiğinde en başarılı ayırma oranı \% 96.60 ile 400 grubunda belirlenmiștir. Bunu \% 46.30 ile 200 A ve \% 36.40 ile 400 A (Ç.B.) takip etmiștir. En zayıf ayırma oranı \% 3.50 ile 400 A grubunda belirlenmiştir. $\mathrm{Bu}$ gruptaki bitkilerde 
incelenen özellikler yönünden birçoğu birbirine benzer olmuştur.

Tablo 6. Gama dozları uygulanan Tarm-92 arpa çeșidinin $\mathrm{M}_{2}$ generasyonuna ait diskriminant analiz sonuçları

\begin{tabular}{|c|c|c|c|c|c|c|c|c|c|}
\hline \multirow{2}{*}{$\begin{array}{l}\text { Uygulama dozu } \\
\text { (Gy) }\end{array}$} & \multicolumn{9}{|c|}{ Gruplar } \\
\hline & Kontrol & 200 & $200 \mathrm{~A}$ & 300 & $300 \mathrm{~A}$ & 400 & $400 \mathrm{~A}$ & 400 A (Ç.B.) & 500 \\
\hline Kontrol & 53 & 9 & 24 & 35 & 53 & 0 & 21 & 10 & 40 \\
\hline 200 & 0 & 15 & 7 & 7 & 5 & 1 & 8 & 3 & 2 \\
\hline $200 \mathrm{~A}$ & 8 & 23 & 81 & 26 & 25 & 0 & 13 & 20 & 51 \\
\hline 300 & 0 & 10 & 2 & 14 & 6 & 0 & 2 & 1 & 3 \\
\hline $300 \mathrm{~A}$ & 0 & 14 & 9 & 17 & 50 & 5 & 39 & 0 & 7 \\
\hline 400 & 0 & 8 & 1 & 41 & 67 & 141 & 65 & 0 & 0 \\
\hline $400 \mathrm{~A}$ & 0 & 42 & 6 & 7 & 2 & 1 & 6 & 4 & 3 \\
\hline $400 \mathrm{~A}$ (C..B.) & 26 & 13 & 28 & 27 & 23 & 1 & 13 & 28 & 46 \\
\hline 500 & 13 & 6 & 17 & 19 & 25 & 0 & 3 & 11 & 28 \\
\hline $\mathrm{N}$ & 100 & 140 & 175 & 193 & 256 & 149 & 170 & 77 & 180 \\
\hline B.0. (\%) & 53.0 & 10.7 & 46.3 & 7.3 & 19.5 & 94.6 & 3.5 & 36.4 & 15.6 \\
\hline \multicolumn{10}{|c|}{ Ayırmadaki toplam bașarı oranı: 0.29} \\
\hline
\end{tabular}

$\mathrm{N}:$ Örnek sayısı $\quad$ B.O.: Benzerlik Oranı

Tablo 7. Doğrusal ayırma fonksiyonları

\begin{tabular}{|c|c|c|c|c|c|c|c|c|c|}
\hline $\begin{array}{l}\text { Ayırma } \\
\text { Fonk. sabiti }\end{array}$ & Kontrol & 200 & $200 \mathrm{~A}$ & 300 & $300 \mathrm{~A}$ & 400 & $400 \mathrm{~A}$ & $\begin{array}{l}400 \mathrm{~A} \\
\text { (C..B.) }\end{array}$ & 500 \\
\hline & -23.48 & -2165 & -20.97 & -19.04 & -17.22 & -23.77 & -22.44 & -23.13 & -20.26 \\
\hline B. B. & 0.02 & -0.02 & -0.05 & 0.01 & -0.01 & 0.02 & 0.01 & 0.01 & 0.00 \\
\hline B. U. & 3.16 & 3.39 & 3.44 & 3.06 & 2.99 & 3.40 & 3.31 & 3.63 & 3.22 \\
\hline B. T. S. & 0.63 & 0.77 & 0.62 & 0.70 & 0.70 & 1.03 & 0.84 & 0.56 & 0.55 \\
\hline B. T. A. & 1.23 & -0.69 & 1.20 & -0.73 & -0.92 & -4.31 & -1.77 & 0.60 & 0.94 \\
\hline
\end{tabular}

B.B.: Bitki Boyu; B.U.: Başak Uzunluğu; B.T.S.: Başakta Tane Sayısı; B.T.A.: Başakta Tane Ağırlığı

Doğrusal ayırma fonksiyonlarını içeren katsayılar incelendiğinde en etkin özelliğin başak uzunluğu olduğu belirlenmiștir. Yine, tane sayısı ve bașakta tane ağırlığından elde edilen katsayıların daha yüksek olması incelenen bitkileri ayırmada etkili olabileceğini göstermektedir. Bu çalışmada en zayıf ayırma katsayısı bitki boyunda belirlenmiştir (Tablo 7).

Araştırmada $\mathrm{M}_{2}$ generasyonunda yaşayan bitki oranı yönünden değerlendirildiğinde en yüksek 300 Gy uygulamasında elde edilmiştir. Bu durum kontrole benzeyen özelliklere sahip bitki sayısının 300 Gy grubunda daha fazla olmasına neden olmuş olabilir. Yine, 500 Gy dozu uygulamasinda kontrole benzeyen bitki oranı daha fazla bulunmuștur. Yaşayan bitkilerin radyasyondan etkilenmemiş̧ olabileceğini göstermektedir.

\section{Sonuç}

Araștırmada 300 ve 400 Gy uygulamalarında incelenen özellikler yönünden daha fazla varyasyon oluştuğu belirlenmiştir. Doğrusal ayırma fonksiyonlarını göre en etkin özelliğin başak uzunluğu, en zayıf ayırma katsayısı ise bitki boyunda belirlenmiștir. Yine, tane sayısı ve başakta tane ağırlı̆̆ından elde edilen katsayıların daha yüksek olması, incelenen bitkileri ayırmada etkili olabileceğini göstermektedir. Araştırmada her uygulama grubunda incelenen başaklara ayrı numara verilmiş ve başak uzunluğu ile başakta tane sayısı yönünden istenilen özelliklere sahip olanlar seçilerek $\mathrm{M}_{3}$ generasyonu oluşturulmuştur.

\section{Teşekkür}

Bu çalışma Tuğçe Ayşe KARAKOCA'nın yüksek lisans tezinden alınmıştır.

\section{Kaynakça}

[1] Alkan, F. R., Kandemir, N. 2015. Tokak Yerel Arpa Çeşidi İçinden Seçilen Saf hatların Bazı Gıda, Yem ve Tarımsal Özellikler Bakımından Varyasyonları. Tarla Bitkileri Merkez Araştırma Enstitüsü Dergisi, 24 (2), 124-139.

[2] Sipahi, H., Sayım, İ., Ergün, N., Çetin, G. 2010. Maltlık Kalitesi Yüksek Arpa (Hordeum vulgare L.) Çeşitlerinin Geliştirilmesi. (Biyoteknoloji iş paketi: İkiye katlanmış haploid bitkilerin üretilmesi). Tübitak Projeleri. Maltlık Arpa Geliștirme Projesi (TÜBİTAK1007-KAMAG 105 G 083) 2006-2010.

[3] Anonim, 2019. Tarım Ürünleri Piyasası Arpa. https://arastirma.tarimorman.gov.tr/tepge/Bel geler/PDF\%20Tarım\%20Ürünleri\%20Piyasalar 1/20180cak\%20Tarım\%20Ürünleri\%20Raporu /2018-Ocak\%20Arpa.pdf (Erişim Tarihi: 21.10.2019).

[4] Sirat, A., Sezer, İ. 2009. Bafra Ovası Koşullarına Uygun Arpa (Hordeum vulgare L.) Çeşitlerinin Belirlenmesi. Anadolu Tarım Bilimleri Dergisi, 24(3), 167-173.

[5] Micke, A., Donini, B., Maluszynski, M. 1987. Induced Mutations for Crop Improvement-a 
review. Tropical Agricultural (Trinidad), 64 (4), 259-278.

[6] Maluszynski, M., Nichterlein, K., Van Zanten, L., B. S. Ahloowalia, B. S. 2000. Officially Released Mutant varieties-the FAO/IAEA Database. Mut. Breed. Rev., 12: 1-84.

[7] Latif, A., Siddiqui, S. H., Aqeel, M., Khan, F. M., Khan, H., 1995. Variation in Genetic Parameters of Barley and Triticale After Seed Irradiation. Sarhad Journal of Agriculture, 11 (5), 627-630.

[8] Din, R., Qasim, M., Ahmad, K., Jehan, S., 2003. Study of Days Taken to Earing Initiation and Earing Completion in $\mathrm{M}_{1}$ Generation of Different Wheat Genotypes Irradiated with Various Doses of Gamma Radiation. Asian Journal of Plant Science, 2 (12), 894-896.

[9] Maluszynski, M., Iwona Szarejko, I., Bhatia, C. R. Nichterlein, K. Pierre, J. L. Lagoda, P. J. L. 2009. Methodologies for generating variability. In: Ceccarelli S., Guimar E. P., Weltzien E., editors. Plant breeding and farmer participation.Rome: Food and Agriculture Organization (FAO);http://www.fao.org/docrep/012/i1070e /i1070e00.htm (Erişim Tarihi: 10.10.2019).

[10] Çelebi, Y. 2016. İki Sıralı Tokak Arpa (Hordeum vulgare L.) Çeşidi ile Bundan Elde Edilen Mutant Hatların Bazı Fenolojik ve Tarımsal Özellikler Yönünden Karşılaştırılması. Atatürk Üniversitesi, Fen Bilimleri Fakültesi, Yüksek Lisans Tezi, 53s, Erzurum.

[11] Turan, H. N., 2007. Gama işınlamanın makarnalık buğday bitkisinde (Triticum durum Desf.) haploid embriyo üretimi ve bitki regenerasyonuna etkisi. Süleyman Demirel Üniversitesi, Fen Bilimleri Üniversitesi, Yüksek Lisans Tezi, 56s, Isparta.

[12] McClung, A. M., Cantrell, R. G., Quick, J. S., Gregory, R. S. 1986 Influence of the Rht1 Semidwarf Gene on Yield Component and Grain Protein in Durum Wheat. Crop Science, 26, 1095-1098.

[13] Bilgen, G. 1989. Yabani x kültür arpa melezlerinde genetik analizi ve bunlardan ıslahta yararlanma olanakları. Ege Ünüversitesi, Fen bilimleri Enstitüsü, Doktora Tezi, 82s, İzmir.

[14] Bilge, E., Ersoy, G. 1972. Streptomicin, X Işınları ve Gamma Işınları ile Muamelenin Hordeum vulgare (arpa) Üzerine Etkileri. Türk Biyoloji Dergisi, 22, 42-49.

[15] Başer, İ., Bilgin, O., Sara, E., Yorgancılar, Ö. 1997. Uzun Boylu Makarnalık Buğday Çeşitlerine Uygulanan Farklı Dozdaki Gamma Işınlarının Bitki Boyu, Tane Verimi ve Bazı Tarımsal Özellikler Üzerine Etkisi. II. Tarla Bitkileri Kongresi, 25-27 Eylül, Samsun, 26-31.
[16] Katipoğlu, H. T. 1995. Kaya (Hordeum distichon) ve Gem (Hordeum vulgare) arpa çeşitlerinin tohumlarına uygulanan farklı dozlardaki gamma (J) ışınlarının M1 bitkileri üzerindeki etkileri. Çukurova Fen Bilimleri Enstitüsü, Yüksek Lisans Tezi, 81s., Adana.

[17] Bouma, J., Ohnoutka, Z. 1991. Importance and Application of the Mutant 'Diamant' in Spring Barley Breeding. In: Plant Mutation Breeding for Crop Improvement. 1. IAEA, Vienna, 127-133.

[18] Güllap, M. K. 2006. Yazlık iki sıralı arpa (Hordeum vulgare L.)'da mutant çeşit adaylarının belirlenmesi. Atatürk Üniversitesi, Fen Bilimleri Enstitüsü, Yüksek Lisans Tezi, 54 s., Erzurum.

[19] Başer, İ., Bilgin, O., Korkut, K., Balkan, A. 2007. Makarnalık Buğdayda Mutasyon Islahı ile Bazı Kantitatif Karakterlerin Geliştirilmesi. Tarım Bilimleri Dergisi, 13 (4), 346-353.

[20] Koç, A., Akgün, İ. 2018. Batı Akdeniz'de ICARDACIMMYT Ekmeklik Buğday Genotiplerinin Verim ve Kalite Yönünden Karşılaştırılması. Ziraat Mühendisliği Dergisi, 365, 22-33.

[21] Başar, H., Tümsavaş, Z., Katkat, A., V., Özgümüş, A. 1998. Saraybosna Buğday Çeşidinin Verim ve Bazı Verim Kriterleri Üzerine Değişik Azotlu Gübrelerin ve Azot Dozlarının Etkisi. Turkish Journal of Agriculture and Forestry, 22, 56-63.

[22] Yıldırım M., Budak N. 1989. Progeny Testing Results of Lines Selected from Mutant Population of Kaya Barley Cultivar. Ege Üniversitesi Ziraat Fakültesi Fakültesi Dergisi, 26, 79-86.

[23] Kubba, A. J., Ibrahim, F. 1989. Semi Dwarf Mutants from Bread Wheat Cultivar Inia 66. Mutation Breeding Newsletter, 34, 10-12.

[24] Butnaru, G. 1991. Mutagenesis in Triticale. National Wheat Research Center, Proceedings of the Second International Triticale Symposium Mexico DF (Mexico) CIYMMT, p. 154156.

[25] Singh, M., Khanna, V. K. 1988. Effect of Gamma Radiations on the Crossability of Wheat, Triticale and Rye and on Meiosis, Pollen Grain Germination and Pollen Tube Growth. Cytology, 53, 123-130.

[26] Akgün, İ., Tosun, M. 2004. Agricultural and Cytological Characteristics of $\mathrm{M}_{1}$ Perennial Rye (Secale montanum Guss.) as Effected by the Application of Different Doses of Gamma Rays. Pakistan Journal of Biological Sciences, 7 (5), 827-833.

[27] Çiftçi, C. Y., Akbay, G., Ünver, S. 1988. Kunduru1149 (Triticum durum L.) Makarnalık Buğday Çeşidine Uygulanan Farklı EMS (Ethyl Methane Sulphonate) Dozlarının $\mathrm{M}_{1}$ Bitkilerinin Bazı Özellikleri Üzerine Etkileri, I. Ankara 
Üniversitesi, Ziraat Fakültesi Yıllığı, 39 (1-2) 337-342.

[28] Tutluer, M. İ. 1993. Çok yıllık çavdar (Secale montanum Guss.)'dan gamma radyasyon ile yem çavdarı elde etme imkanları ve mitoz mayoz bölünmelerde görülen değişiklikler. Ankara Üniversitesi, Fen Bilimleri Enstitüsü, Doktora Tezi, 144s, Ankara.

[29] Rachovska, G., Dimova, D. 2000. Effect of Sodium Azide and Gamma Rays on $\mathrm{M}_{1}$ Quantitative Characteristicts of the Productivity and their Connection with $\mathrm{M}_{2}$ Mutation Changes in Winter Common Wheat. Rateniev'dni Nauki, 37 (7). 413-419.

[30] Yıldırım, M. B., Çağırgan, M. I., Turgut, I. 1987. Arpa Mutant Populasyonlarında Seleksiyon Uygulaması. Türkiye Tahıl Sempozyumu, 6-9 Ekim, Bursa, 473-481.

[31] Eser, D., Sağel, Z., Tutluer, M. I., Peşkircioğlu, H., Atilla, A. S. 1991. The Effect of Gamma Radiation Doses on Some Characters in $\mathrm{M}_{1}$ Generation of Large Seeded Type Green Lentil Pul-11 Cultivar. Turkish Journal of Nuclear Sciences, 18 (2), 5-15.

[32] Peşkircioğlu, H., Tutluer, M., Sağel, Z., Şenay, A. 1996. Mutant Arpa Popülasyonunda Bazı Verim Öğelerindeki Varyasyonun Saptanması. IV.
Ulusal Nükleer Tarım ve Hayvancılık Kongresi, 25-27 Eylül, Bursa, 58-63.

[33] Sirat, A., Sezer, İ. 2017. Bafra Ovasında Yetiştirilen Bazı İki Sıralı Arpa (Hordeum vulgare conv. distichon) Çeşitlerinin Verim, Verim Öğeleri ile Bazı Kalite Özelliklerinin Belirlenmesi. Tekirdağ Ziraat Fakültesi Dergisi, 14(1), 77-87.

[34] İmamoğlu, A., Yılmaz, N. 2012. Bursa Ekolojik Koşullarında Bazı Arpa (Hordeum vulgare L.) Genotiplerinin Verim ve Bazı Kalite Özelliklerinin Belirlenmesi. Anadolu Dergisi, 22 (2), 13 - 36.

[35] Balkan, A., Bilgin, O., Başer, İ., Balaban, D. G., Demirkan, A. K., Deviren, B. 2019. Ekmeklik Buğday (Triticum aestivum L.) Genotiplerinde Tane Verimi ve Verimli İlişkili Özelliklerin Gama Işını Kullanılarak Mutasyon Islahı İle Geliştirilmesi. Tekirdağ Ziraat Fakültesi Dergisi, 16 (1), 97-105.

[36] Khan, K., Ilbal, M., Azim, F., Sher, H. 2003. Effect of Gamma Irradiation on Yield and Yield Components of Barley (Hordeum vulgare L.)Pakistan Journal of Biological Sciences, 6 (19), 1695-1697. 